\title{
Baseline Sensitivity of Penicillium spp. to Difenoconazole
}

Wayne M. Jurick II, ${ }^{\dagger}$ Otilia Macarisin, and Verneta L. Gaskins, Food Quality Laboratory, USDA-ARS, Beltsville Agricultural Research Station, Beltsville, MD 20705; Wojciech J. Janisiewicz, Appalachian Fruit Research Station, USDA-ARS, Kearneysville, WV, 25430; Kari A. Peter, Department of Plant Pathology and Environmental Microbiology, Penn State University, Fruit Research and Extension Center, Biglerville, PA 17307; and Kerik D. Cox, Section of Plant Pathology and Plant-Microbe Biology, School of Integrative Plant Science, Cornell University, Geneva, NY, 14456

\begin{abstract}
Penicillium spp. cause blue mold of stored pome fruit. These fungi reduce fruit quality and produce mycotoxins that are regulated for processed fruit products. Control of blue mold is achieved by fungicide application, and in 2015 Academy (active ingredients fludioxonil and difenoconazole) was released for use on pome fruit to manage postharvest blue mold. Baseline sensitivity for fludioxonil but not difenoconazole has been determined for $P$. expansum. To establish the distribution of sensitivity to difenoconazole before commercial use of Academy, 97 unexposed single-spore isolates from the United States and abroad were tested in vitro. Baseline $\mathrm{EC}_{50}$ values ranged from 0.038 to $0.827 \mu \mathrm{g} / \mathrm{ml}$ of difenoconazole with an average of $0.16 \mu \mathrm{g} / \mathrm{ml}$.

Complete inhibition of mycelial growth for all but three isolates occurred at $5 \mu \mathrm{g} / \mathrm{ml}$ of difenoconazole, whereas $10 \mu \mathrm{g} / \mathrm{ml}$ did not support growth for any of the isolates examined. Hence, $5 \mu \mathrm{g} / \mathrm{ml}$ of difenoconazole is recommended for phenotyping Penicillium spp. isolates with reduced sensitivity. Isolates with resistance to pyrimethanil and to both thiabendazole and pyrimethanil were observed among the isolates from the baseline collection. Academy applied at the labeled rate had both curative and protectant activities and controlled four representative Penicillium spp. from the baseline population. This information can be used to monitor future shifts in sensitivity to this new postharvest fungicide in Penicillium spp. populations.
\end{abstract}

Penicillium expansum (Link) Thom. and other Penicillium spp. cause blue mold and are the most common and economically important postharvest fruit rot pathogens of apples (Rosenberger 1990; Xiao and Boal 2009). A survey of postharvest diseases in Washington State revealed that blue mold accounted for $28 \%$ of fruit decays in storage (Xiao and Kim 2008). The disease is characterized by a soft, watery, light-brown rot that is accompanied by the appearance of blue-green colored conidia on the fruit surface that develops at advanced stages of decay. P. expansum and other Penicillium spp. usually invade wounds such as stem punctures or bruises that occur before, during, and after harvest. Infection also proceeds via natural openings such as lenticels, open calyx or sinus, and stem pull areas. The fungus has also been reported to enter the fruit through stem ends on 'Empire' apple fruit (Errampalli 2004; Rosenberger et al. 2006). A survey of apples and pears with blue mold symptoms from Oregon and Washington State was conducted and showed that several additional Penicillium spp. ( $P$. aurantiogriseum, $P$. commune, $P$. solitum, $P$. verrucosum, and $P$. expansum) cause blue mold decay (Sanderson and Spotts 1995). A similar survey was also conducted in British Columbia, in which $P$. brevicompactum, P. crustosum, and P. expansum were isolated from apple fruit with blue mold (Sholberg and Haag 1996). Additionally, $P$. paneum and $P$. carneum (unpublished data) were found causing blue mold on stored apple fruit, and they

${ }^{\dagger}$ Corresponding author: W. M. Jurick II; E-mail: wayne.jurick@ars.usda.gov

Funding: This work was supported by base funds provided to USDA-ARS project plan \#8042-42430-002-00D entitled "Development of Novel Tools to Manage Fungal Plant Pathogens That Cause Postharvest Decay of Pome Fruit to Reduce Food Waste" via USDA-ARS National Program 303 Plant Diseases. This work was also partially supported by competitive extramural grant funds awarded to PI W. M. Jurick II and Co-PI K. A. Peter via State Horticultural Association of Pennsylvania.

Mention of trade names or commercial products in this publication is solely for providing specific information and does not imply recommendation or endorsement by the U.S. Department of Agriculture.

Accepted for publication 14 August 2018.

This article is in the public domain and not copyrightable. It may be freely reprinted with customary crediting of the source. The American Phytopathological Society, 2019. proved to be pathogenic on apple via Koch's postulates (Peter et al. 2012). Previously, these two pathogens, which are closely related to $P$. roqueforti, have been associated with spoilage of meats, beverages, bread, and silage (Boysen et al. 1996; Frisvad and Samson 2004).

Apples are stored for extended periods of time in air (up to 6 months at $1^{\circ} \mathrm{C}$ ) or in a controlled atmosphere (up to 1 year) to provide fruit year-round to meet customer demands. Presently, there is no resistance in commercial apple cultivars to the necrotrophic fungal pathogens that cause postharvest decay, including Penicillium spp. (Spotts et al. 1999). Long-term storage, coupled with lack of host resistance, provides limited options for industry to rely on fungicides and biological control products (i.e., BioSave) to manage postharvest decay of pome fruit (Errampalli and Brubacher 2006; Janisiewicz and Jeffers 1997; Rosenberger 2012; Xiao and Boal 2013). Postharvest fungicide applications vary depending on the stage of handling and are typically applied in bin drenches before storage, sprays on sorting lines, dips, application with waxes, or thermofogging in storage rooms. Five fungicides (Academy, Captan, Mertect, Penbotec, and Scholar) are registered to control blue mold on apples the United States. Both Scholar (active ingredient, fludioxonil [FLU]) and Penbotec (active ingredient, pyrimethanil [PYR]) were labeled for postharvest use in 2004 (Xiao and Boal 2009).

Recent reports have demonstrated that reduced efficacy of the postharvest fungicides has resulted in increasing blue and gray mold decays in commercially stored apple fruit in Pennsylvania (Gaskins et al. 2015; Yan et al. 2014). Thiabendazole (TBZ), marketed as Mertect, was labeled for blue mold management in 1968 and is applied as a drench prior to storage. Repeated long-term use of TBZ along with other benzimidazole fungicides (benomyl and thiophanate-methyl, which are no longer registered) resulted in development of benzimidazole-resistant Penicillium spp. throughout the apple-growing regions of the United States and Canada (Bertrand and Saulie-Carter 1978; Rosenberger 1990; Sholberg and Haag 1996). A new fungicide product marketed as Academy (Syngenta, Greensboro, NC) was introduced in 2015 and contains two ingredients, FLU (active ingredient $12.5 \%$ ) and difenoconazole (active ingredient 20.9\%), to manage blue mold on pome fruits in storage. Although four postharvest fungicides with different modes of action are commercially in use, their rotation is imperative to reduce development of resistance and maintain efficacy. Establishment 
of the baseline sensitivity distribution is the first important step in developing a fungicide resistance monitoring and management strategy (Russell 2004). Although previous baseline sensitivity data have been generated for TBZ, FLU, and PYR, it has not been developed for difenoconazole (Li and Xiao 2008).

The objectives of the present study were to (i) establish a baseline sensitivity distribution to difenoconazole in an unexposed Penicillium spp. collection, (ii) determine the occurrence of fungicide resistance to postharvest fungicides (TBZ, PYR, and FLU) in representative members of the difenoconazole baseline population, (iii) examine the ability of Academy to control blue mold decay incited by Penicillium spp. isolates with a range of sensitivity to difenoconazole, and (iv) investigate the curative and protectant ability of Academy to control blue mold under commercial cold storage and conditions.

\section{Materials and Methods}

Fungal isolate collection, identification, and storage. From May 2010 to February 2013, decayed fruit from different apple cultivars were sampled from farm stands and commercial facilities in Pennsylvania and Maryland. Depending on the year and location, some fruit were known to have been treated with PYR or FLU prior to storage. Decayed fruit were collected from cull piles, storage bins, and display cases. Water samples $(50 \mathrm{ml})$ for isolation of Penicillium spp.

Table 1. Penicillium spp. isolates analyzed for baseline sensitivity to difenoconazole

\begin{tabular}{|c|c|c|c|c|c|c|c|c|c|c|}
\hline Isolate & Year & $\begin{array}{c}\text { Host, source, } \\
\text { or cultivar }^{x} \\
\end{array}$ & Location & $\begin{array}{l}\text { U.S. state } \\
\text { or country }\end{array}$ & Species $^{\mathrm{z}}$ & $\% \mathrm{ID}^{\mathrm{z}}$ & e value & $\begin{array}{l}\text { GenBank } \\
\text { accession } \\
\end{array}$ & $\begin{array}{l}\text { Mean } \\
\text { EC }_{50} \mathbf{z}^{-} \\
\end{array}$ & $\mathbf{Q R}^{\mathbf{z}}$ \\
\hline 28890 & 1974 & Pear & Unknown & $\mathrm{CA}$ & P. expansum & 99 & 0 & FJ012858.1 & 0.11 & 3 \\
\hline 28893 & 1974 & Apricot & Unknown & $\mathrm{CA}$ & P. chrysogenum & 100 & 0 & AM920428.1 & 0.13 & 3 \\
\hline 28895 & 1974 & Persimmon & Unknown & $\mathrm{CA}$ & P. expansum & 100 & 0 & FJ012858.1 & 0.14 & 3 \\
\hline 28889 & 1974 & Asian pear & Unknown & $\mathrm{CA}$ & P. expansum & 99 & 0 & FJ012847.1 & 0.53 & 4 \\
\hline 28886 & 1974 & Grape & Unknown & $\mathrm{CA}$ & P. expansum & 99 & 0 & FJ012858.1 & 0.82 & 4 \\
\hline 42710 & 1978 & Apple & Unknown & Netherlands & P. expansum & 100 & 0 & KY426817.1 & 0.05 & 1 \\
\hline F-Fr-C-2 & 1988 & Apple & Unknown & WV & P. expansum & 100 & 0 & JN872743.1 & 0.04 & 1 \\
\hline F-Fr-MD-8 & 1988 & Apple & Unknown & WV & P. expansum & 100 & 0 & JN872743.1 & 0.07 & 2 \\
\hline F-Fr-J-8 & 1988 & Apple & Unknown & WV & P. expansum & 100 & 0 & FJ012858.1 & 0.10 & 3 \\
\hline F-Fr-C-3 & 1988 & Apple & Unknown & WV & P. solitum & 99 & 0 & FJ012875.1 & 0.42 & 4 \\
\hline F-Fr-J-6 & 1988 & Apple & Unknown & WV & P. expansum & 100 & 0 & FJ012858.1 & 0.45 & 4 \\
\hline 99004 & 2002 & Unknown & Unknown & Unknown & P. solitum & 100 & 0 & FJ012875.1 & 0.05 & 1 \\
\hline 99001 & 2002 & Unknown & Unknown & Unknown & P. solitum & 100 & 0 & FJ012873.1 & 0.09 & 3 \\
\hline 3354 & 2004 & GD & Storage & WA & P. expansum & 100 & 0 & FJ012853.1 & 0.06 & 2 \\
\hline SA4 & 2010 & $\mathrm{~F}$ & Farm stand & MD & P. expansum & 100 & 0 & FJ012847.1 & 0.05 & 1 \\
\hline SA19 & 2010 & $\mathrm{~F}$ & Farm stand & MD & P. expansum & 100 & 0 & FJ012858.1 & 0.38 & 4 \\
\hline SA1 & 2010 & $\mathrm{~F}$ & Farm stand & MD & P. expansum & 100 & 0 & JN872743.1 & 0.39 & 4 \\
\hline SA6 & 2010 & $\mathrm{~F}$ & Farm stand & MD & P. brevicompactum & 90 & 0 & JF302652.1 & 0.55 & 4 \\
\hline P11 & 2011 & PL & Storage & PA & P. expansum & 100 & 0 & FJ012853.1 & 0.04 & 1 \\
\hline P9 & 2011 & PL & Storage & $\mathrm{PA}$ & P. expansum & 100 & 0 & FJ012847.1 & 0.04 & 1 \\
\hline R14 & 2011 & $\mathrm{RD}$ & Storage & PA & P. crustosum & 99 & 0 & JN112030.1 & 0.04 & 1 \\
\hline F21 & 2011 & $\mathrm{~F}$ & Storage & $\mathrm{PA}$ & P. expansum & 100 & $6.00 \mathrm{E}-172$ & JN872743.1 & 0.04 & 1 \\
\hline P24 & 2011 & PL & Storage & PA & P. expansum & 100 & 0 & FJ012853.1 & 0.05 & 1 \\
\hline G12 & 2011 & GD & Storage & PA & P. expansum & 100 & 0 & JN872745.1 & 0.05 & 1 \\
\hline SAR1 & 2011 & $\mathrm{RD}$ & Farm stand & MD & P. expansum & 100 & 0 & FJ012858.1 & 0.05 & 1 \\
\hline F16 & 2011 & $\mathrm{~F}$ & Storage & PA & P. expansum & 100 & 0 & FJ012847.1 & 0.05 & 1 \\
\hline P4 & 2011 & PL & Storage & $\mathrm{PA}$ & P. expansum & 100 & 0 & FJ012853.1 & 0.05 & 1 \\
\hline $\mathrm{SAH} 2$ & 2011 & $\mathrm{HC}$ & Farm stand & MD & P. expansum & 100 & 0 & JN872745.1 & 0.05 & 1 \\
\hline G9 & 2011 & GD & Storage & $\mathrm{PA}$ & P. paneum & 99 & 0 & JF302651.1 & 0.05 & 1 \\
\hline R27 & 2011 & $\mathrm{RD}$ & Storage & $\mathrm{PA}$ & P. expansum & 100 & 0 & FJ012853.1 & 0.05 & 1 \\
\hline G21 & 2011 & GD & Storage & PA & P. expansum & 100 & 0 & JN872745.1 & 0.05 & 1 \\
\hline SAR7 & 2011 & $\mathrm{RD}$ & Farm stand & MD & P. expansum & 100 & 0 & JN872743.1 & 0.05 & 1 \\
\hline G6 & 2011 & GD & Storage & PA & P. expansum & 100 & 0 & KY426817.1 & 0.05 & 1 \\
\hline P13 & 2011 & PL & Storage & $\mathrm{PA}$ & P. expansum & 100 & 0 & FJ012847.1 & 0.05 & 1 \\
\hline $\mathrm{R} 2$ & 2011 & $\mathrm{RD}$ & Storage & PA & P. expansum & 100 & 0 & JN872743.1 & 0.06 & 2 \\
\hline R21 & 2011 & $\mathrm{RD}$ & Storage & $\mathrm{PA}$ & P. expansum & 100 & 0 & KY426817.1 & 0.06 & 2 \\
\hline G15 & 2011 & GD & Storage & $\mathrm{PA}$ & P. expansum & 99 & 0 & JN872743.1 & 0.06 & 2 \\
\hline SAF1 & 2011 & $\mathrm{~F}$ & Farm stand & MD & P. expansum & 100 & 0 & FJ012858.1 & 0.06 & 2 \\
\hline P17 & 2011 & PL & Storage & $\mathrm{PA}$ & P. expansum & 100 & 0 & FJ012847.1 & 0.06 & 2 \\
\hline $\mathrm{P} 1$ & 2011 & PL & Storage & PA & P. expansum & 100 & 0 & JN872745.1 & 0.06 & 2 \\
\hline G11 & 2011 & GD & Storage & PA & P. expansum & 100 & 0 & FJ012847.1 & 0.06 & 2 \\
\hline R13 & 2011 & $\mathrm{RD}$ & Storage & PA & P. expansum & 100 & 0 & JN872743.1 & 0.06 & 2 \\
\hline P6 & 2011 & PL & Storage & PA & P. expansum & 100 & 0 & FJ012847.1 & 0.06 & 2 \\
\hline $\mathrm{P} 15$ & 2011 & PL & Storage & $\mathrm{PA}$ & P. expansum & 100 & 0 & FJ012853.1 & 0.06 & 2 \\
\hline SAH4 & 2011 & $\mathrm{HC}$ & Farm stand & MD & P. expansum & 100 & 0 & FJ012858.1 & 0.07 & 2 \\
\hline $\mathrm{P} 21$ & 2011 & PL & Storage & $\mathrm{PA}$ & P. expansum & 100 & 0 & FJ012853.1 & 0.07 & 2 \\
\hline
\end{tabular}

(Continued on next page)

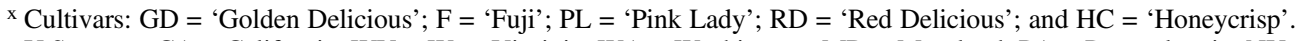

y U.S. states: $\mathrm{CA}=$ California; $\mathrm{WV}=$ West Virginia; $\mathrm{WA}=$ Washington; $\mathrm{MD}=$ Maryland; $\mathrm{PA}=$ Pennsylvania; $\mathrm{NY}=$ New York; and OR $=$ Oregon.

${ }^{\mathrm{z}}$ Species level identification was confirmed via Basic Local Alignment Search Tool (BLAST) using $2 \times$ consensus sequences of a portion of the $\beta$-tubulin gene, including \% identity (\% ID), e value, quartile rank (QR), and mean $\mathrm{EC}_{50}$ (the estimated concentration of a fungicide that results in 50\% inhibition of mycelial growth) for each isolate.
} 
from a commercial packing facility were obtained from water flumes during presizing. Conical tubes were centrifuged to pellet debris, and supernatant was dilution plated onto acidified potato dextrose agar (PDA) to yield single, well separated colonies. To isolate Penicillium spp., symptomatic fruit were surface sanitized with $70 \%$ ethanol, and the central portion of the lesion margin was plated onto PDA. Cultures were transferred to fresh PDA, single spored, and stored as PDA slants at $4{ }^{\circ} \mathrm{C}$. Additional isolates from different geographic locations, hosts, and species were obtained from collaborators, ATCC, and the USDA-ARS NRRL. All isolates were identified to species morphologically and via partial sequence analysis of the $\beta$-tubulin gene (Pitt 2002; Sholberg et al. 2005). Species-level diagnosis was confirmed via MegaBlast analysis at NCBI using $2 \times$ consensus amplicon sequences.

Determination of baseline $\mathbf{E C}_{\mathbf{5 0}}$ values. Ninety-seven isolates, not previously exposed to difenoconazole, from a variety of sources, hosts, and locations were tested for sensitivity to difenoconazole using a mycelial growth assay (Table 1). Technical-grade difenoconazole (Syngenta) was dissolved in acetone, adjusted to a concentrated stock solution, and added to molten PDA to achieve final concentrations of $0,0.05,0.1,0.5,1,2.5,5$, and $10 \mu \mathrm{g} / \mathrm{ml}$ of difenoconazole in $4.5-\mathrm{cm}$ Petri plates. Acetone carrier was included for comparison at the maximum rate, and no carrier effect was observed. Sporulating cultures growing on PDA in 9-cm Petri plates were used as a source

Table 1. (Continued from previous page)

\begin{tabular}{|c|c|c|c|c|c|c|c|c|c|c|}
\hline Isolate & Year & $\begin{array}{l}\text { Host, source, } \\
\text { or cultivar }{ }^{\mathbf{x}}\end{array}$ & Location & $\begin{array}{l}\text { U.S. state } \\
\text { or country }\end{array}$ & Species $^{\mathrm{z}}$ & $\% \mathrm{ID}^{\mathrm{z}}$ & e value & $\begin{array}{l}\text { GenBank } \\
\text { accession }\end{array}$ & $\begin{array}{l}\text { Mean } \\
\mathbf{E C}_{50}{ }^{\mathrm{z}}\end{array}$ & $\mathbf{Q R}^{\mathbf{z}}$ \\
\hline SAH3 & 2011 & $\mathrm{HC}$ & Farm stand & MD & P. expansum & 100 & 0 & FJ012858.1 & 0.07 & 2 \\
\hline SAF2 & 2011 & $\mathrm{~F}$ & Farm stand & MD & P. expansum & 100 & 0 & FJ012858.1 & 0.07 & 2 \\
\hline SAH5 & 2011 & $\mathrm{HC}$ & Farm stand & MD & P. expansum & 100 & 0 & FJ012847.1 & 0.07 & 2 \\
\hline SAR11 & 2011 & $\mathrm{RD}$ & Farm stand & MD & P. expansum & 100 & 0 & JN872745.1 & 0.07 & 2 \\
\hline F6 & 2011 & $\mathrm{~F}$ & Storage & PA & P. expansum & 100 & 0 & FJ012858.1 & 0.08 & 3 \\
\hline R19 & 2011 & $\mathrm{RD}$ & Storage & PA & P. expansum & 100 & 0 & KY426817.1 & 0.08 & 3 \\
\hline SAR14 & 2011 & $\mathrm{RD}$ & Farm stand & MD & P. expansum & 100 & 0 & FJ012858.1 & 0.08 & 3 \\
\hline $\mathrm{G} 2$ & 2011 & GD & Storage & PA & P. carneum & 100 & 0 & JN872745.1 & 0.08 & 3 \\
\hline $\mathrm{R} 1$ & 2011 & $\mathrm{RD}$ & Storage & $\mathrm{PA}$ & P. crustosum & 99 & 0 & JN112030.1 & 0.08 & 3 \\
\hline SAR4 & 2011 & $\mathrm{RD}$ & Farm stand & MD & P. expansum & 100 & 0 & FJ012858.1 & 0.08 & 3 \\
\hline $\mathrm{F} 2$ & 2011 & $\mathrm{~F}$ & Storage & $\mathrm{PA}$ & P. expansum & 100 & 0 & FJ012847.1 & 0.08 & 3 \\
\hline SAG1 & 2011 & GD & Farm stand & MD & P. expansum & 100 & 0 & FJ012858.1 & 0.08 & 3 \\
\hline SAG3 & 2011 & GD & Farm stand & MD & P. expansum & 100 & 0 & KY426817.1 & 0.09 & 3 \\
\hline $\mathrm{R} 18$ & 2011 & $\mathrm{RD}$ & Storage & $\mathrm{PA}$ & P. expansum & 100 & 0 & JN872743.1 & 0.09 & 3 \\
\hline R22 & 2011 & $\mathrm{RD}$ & Storage & PA & P. expansum & 100 & 0 & JN872743.1 & 0.09 & 3 \\
\hline $\mathrm{R} 11$ & 2011 & $\mathrm{RD}$ & Storage & $\mathrm{PA}$ & P. expansum & 100 & 0 & KY426817.1 & 0.10 & 3 \\
\hline SAH1 & 2011 & $\mathrm{HC}$ & Farm stand & MD & P. expansum & 100 & 0 & JN872743.1 & 0.10 & 3 \\
\hline HP1 & 2011 & $\mathrm{HC}$ & Farm stand & PA & P. expansum & 100 & 0 & FJ012858.1 & 0.12 & 3 \\
\hline R25 & 2011 & $\mathrm{RD}$ & Storage & $\mathrm{PA}$ & P. expansum & 100 & 0 & FJ012847.1 & 0.20 & 4 \\
\hline SAR6 & 2011 & $\mathrm{RD}$ & Farm stand & MD & P. expansum & 100 & 0 & FJ012858.1 & 0.22 & 4 \\
\hline SAR15 & 2011 & $\mathrm{RD}$ & Farm stand & MD & P. expansum & 100 & 0 & FJ012858.1 & 0.27 & 4 \\
\hline $\mathrm{P} 12$ & 2011 & PL & Storage & PA & P. expansum & 100 & 0 & FJ012858.1 & 0.29 & 4 \\
\hline R17 & 2011 & $\mathrm{RD}$ & Storage & PA & P. expansum & 100 & 0 & FJ012853.1 & 0.32 & 4 \\
\hline G8 & 2011 & GD & Storage & PA & P. expansum & 100 & 0 & FJ012853.1 & 0.38 & 4 \\
\hline HP2 & 2011 & $\mathrm{HC}$ & Farm stand & PA & P. expansum & 100 & 0 & FJ012853.1 & 0.49 & 4 \\
\hline G10 & 2011 & GD & Storage & PA & P. expansum & 100 & 0 & FJ012853.1 & 0.53 & 4 \\
\hline G20 & 2011 & GD & Storage & PA & P. crustosum & 99 & 0 & JN112030.1 & 0.59 & 4 \\
\hline IIRS-8a & 2012 & Presizing flume & Storage & PA & P. expansum & 100 & 0 & JN872743.1 & 0.04 & 1 \\
\hline IIRS-8d & 2012 & Presizing flume & Storage & PA & P. expansum & 100 & 0 & JN872743.1 & 0.05 & 1 \\
\hline IIRS7 & 2012 & Presizing flume & Storage & PA & P. expansum & 100 & 0 & FJ012858.1 & 0.05 & 1 \\
\hline IIRS-7b & 2012 & Presizing flume & Storage & PA & P. expansum & 100 & 0 & JN872743.1 & 0.05 & 1 \\
\hline IIRS-11 & 2012 & Presizing flume & Storage & PA & P. expansum & 100 & 0 & KY426817.1 & 0.06 & 2 \\
\hline IIRS-8c & 2012 & Presizing flume & Storage & PA & P. expansum & 100 & 0 & JN872743.1 & 0.06 & 2 \\
\hline IIRS-10, 1B & 2012 & Presizing flume & Storage & PA & P. expansum & 100 & 0 & FJ012853.1 & 0.06 & 2 \\
\hline IIRS-7c & 2012 & Presizing flume & Storage & PA & P. expansum & 100 & 0 & KY426817.1 & 0.07 & 2 \\
\hline IIRS11A & 2012 & Presizing flume & Storage & PA & P. expansum & 100 & 0 & FJ012858.1 & 0.07 & 3 \\
\hline IIRR33 & 2012 & GD & Storage & PA & P. expansum & 100 & 0 & FJ012858.1 & 0.08 & 3 \\
\hline IIRR5 & 2012 & $\mathrm{RD}$ & Storage & $\mathrm{PA}$ & P. expansum & 100 & 0 & FJ012847.1 & 0.17 & 3 \\
\hline Stanley A & 2012 & Peach & Research plot & WV & P. solitum & 99 & 0 & FJ012873.1 & 0.21 & 4 \\
\hline 3RU3 & 2013 & Cull pile & Storage & $\mathrm{PA}$ & P. expansum & 100 & 0 & FJ012858.1 & 0.06 & 2 \\
\hline 3RU4 & 2013 & Cull pile & Storage & PA & P. expansum & 99 & 0 & FJ012858.1 & 0.09 & 3 \\
\hline 3RU10 & 2013 & Cull pile & Storage & PA & P. expansum & 100 & 0 & FJ012847.1 & 0.29 & 4 \\
\hline 3RU11 & 2013 & Cull pile & Storage & PA & P. expansum & 100 & 0 & JN872745.1 & 0.41 & 4 \\
\hline 971 & Unknown & Unknown & Unknown & Unknown & P. chrysogenum & 96 & $1.00 \mathrm{E}-113$ & AM920428.1 & 0.06 & 2 \\
\hline 894 & Unknown & Plant & Unknown & Netherlands & P. expansum & 100 & 0 & FJ012858.1 & 0.07 & 2 \\
\hline 766 & Unknown & Unknown & Unknown & Unknown & P. solitum & 99 & 0 & FJ012875.1 & 0.08 & 3 \\
\hline 16104 & Unknown & Apple & Unknown & NY & P. solitum & 99 & 0 & FJ012875.1 & 0.42 & 4 \\
\hline RS1 & Unknown & Apple & Unknown & OR & P. solitum & 98 & 0 & FJ012875.1 & 0.46 & 4 \\
\hline 864 & Unknown & Unknown & Unknown & Belgium & P. expansum & 100 & 0 & FJ012858.1 & 0.50 & 4 \\
\hline $2159 \mathrm{~A}$ & Unknown & Unknown & Unknown & Unknown & P. solitum & 100 & 0 & JN112030.1 & 0.55 & 4 \\
\hline 35178 & Unknown & Green coffee bean & Unknown & Chiapas, Mexico & P. chrysogenum & 96 & $4.00 \mathrm{E}-113$ & AM920428.1 & 0.71 & 4 \\
\hline
\end{tabular}


of inoculum. Briefly, spores were harvested using $1 \mathrm{ml}$ of filtersterilized $0.1 \%$ aqueous solution of Tween 20 and adjusted to $1 \times$ $10^{5}$ conidia/ml as determined by a hemocytometer. A $10-\mu l$ spore suspension droplet was placed in the middle of each plate. Plates were sealed with Parafilm and placed in a temperature-controlled incubator at $25^{\circ} \mathrm{C}$ with natural light. For each isolate, three replicates per concentration were used, and the experiment was performed two times. For each plate, mean colony diameter was measured after 6 days of incubation and used for calculation of $\mathrm{EC}_{50}$, which is the estimated concentration of a fungicide that results in $50 \%$ inhibition of mycelial growth.

Assessment of fungicide phenotypes and growth rate in Penicillium spp. Eight isolates (seven $P$. expansum and one $P$. solitum) were selected based on quartile rank representing their $\mathrm{EC}_{50}$ for difenoconazole. Three tier 1, one tier 2, one tier 3, and three tier 4 isolates were evaluated for resistance to postharvest fungicides using an in vitro assay and previously published discriminatory doses (Jurick et al. 2017; Li and Xiao 2008). Growth on PDA alone, PDA amended with $10 \mu \mathrm{g} / \mathrm{ml}$ of TBZ, $0.5 \mu \mathrm{g} / \mathrm{ml}$ of FLU, $5.0 \mu \mathrm{g} / \mathrm{ml}$ of difenoconazole, and PDA with solvent carrier was assessed. Additionally, Richards defined medium (Jurick et al. 2017) alone, Richards with acetone carrier, and Richards with $1.0 \mu \mathrm{g} / \mathrm{ml}$ of PYR were also evaluated. Conidial inoculum, plate inoculations, incubation, and colony measurements were made as described previously. No carrier effect was observed for any medium. For each isolate, three replicates per concentration were used, and the experiment was conducted twice. An isolate was considered resistant if mycelial growth was evident and quantifiable growth was obtained on a discriminatory dose described for each compound (Jurick II et al. 2017; Li and Xiao 2008). Growth rate was calculated by measuring colony diameter and dividing by the total number of days (6) of incubation.

Evaluation of Academy to control blue mold of stored apple fruit. To assess the curative and protectant properties of Academy postharvest fungicide, one Penicillium spp. isolate from each fungicide resistance tier ( 1 to 4 ) was selected and used to inoculate Academy-treated fruit. Organic 'Golden Delicious' apples were obtained from a local supermarket and stored at $1{ }^{\circ} \mathrm{C}$ until the experiment was conducted. Apples were surface disinfested by washing them with soap and water followed by spraying with $70 \%$ ethanol until saturation and wiping dry with sterile paper towels. Each fruit was wounded once at the equator with the point of a 3-mm-diameter finishing nail to a $3 \mathrm{~mm}$ depth to simulate stem punctures. The fruit was inoculated by pipetting $20 \mu \mathrm{l}$ of the conidial suspension into each wound. Conidial suspensions (adjusted to $1 \times 10^{5}$ conidia/ml in sterile Tween 20 water) were obtained from sporulating cultures grown at $25^{\circ} \mathrm{C}$. For protectant treatments, fruit were dipped for $3 \mathrm{~min}$ in a solution containing Academy at the labeled rate of $16 \mathrm{fl} \mathrm{oz}$ of formulated product per 100 gal for $3 \mathrm{~min}$, allowed to air dry on paper trays, wounded, and inoculated with the pathogen suspension. Fruit were incubated at $25^{\circ} \mathrm{C}$ for $1 \mathrm{~h}$ until wounds absorbed the conidial suspension. For curative treatments, approximately $1 \mathrm{~h}$ after inoculation with the conidial suspension, fruit were dipped for $3 \mathrm{~min}$ in the Academy solution, air dried for $15 \mathrm{~min}$, placed on fruit trays, and stored in cardboard commercial apple packing boxes at $1{ }^{\circ} \mathrm{C}$ to

Table 2. Analysis of estimated concentration to inhibit 50\% mycelial growth $\left(\mathrm{EC}_{50}\right)$ for difenoconazole in Penicillium species as a function of the entire collection, pome fruit isolates, storage isolates, or by most commonly occurring species ( $P$. expansum)

\begin{tabular}{|c|c|c|c|c|c|c|}
\hline \multirow[b]{2}{*}{ Variable } & \multirow[b]{2}{*}{$N$} & \multirow{2}{*}{$\begin{array}{c}\text { Year } \\
\text { isolated }\end{array}$} & \multicolumn{4}{|c|}{$\mathbf{E C}_{50}$} \\
\hline & & & Range & Mean & Median & Mode \\
\hline $\begin{array}{l}\text { Entire } \\
\text { collection }\end{array}$ & 97 & 1974-2013 & $0.038-0.827$ & 0.16 & 0.07 & 0.05 \\
\hline Pome fruit & 72 & 1974-2012 & $0.040-0.590$ & 0.15 & 0.07 & 0.06 \\
\hline Storage & 53 & 2004-2013 & $0.040-0.590$ & 0.11 & 0.06 & 0.06 \\
\hline P. expansum & 80 & 1974-2013 & $0.040-0.827$ & 0.14 & 0.07 & 0.05 \\
\hline
\end{tabular}

emulate commercial storage conditions. Fruit were assessed after 8 weeks of storage at $1^{\circ} \mathrm{C}$ for decay, and each treatment consisted of 20 fruit. Lesion diameters were measured with a digital micrometer, and disease severity and incidence were calculated. Once fruit were evaluated for decay following 8 weeks of storage at $1^{\circ} \mathrm{C}$, they were incubated for additional 7 days at $20^{\circ} \mathrm{C}$, and the incidence and severity of the decay were recorded again. The experiment was conducted two times.

Statistical and data analysis. Frequencies for difenoconazole $\mathrm{EC}_{50}$, quartile rank, mean, median, and mode were calculated in Microsoft Excel. $\mathrm{EC}_{50}$ values for each fungicide were determined using probit analysis with the PROC PROBIT procedure of SAS (version 9.4, SAS Institute, Cary, NC). Frequencies, range, median, and mode of $\mathrm{EC}_{50}$ of difenoconazole were determined from the values in two independent experiments. For the in vivo fungicide tests, blue mold incidence was arcsine-square-root transformed prior to analysis to stabilize the variance. The effect of fungicide treatments in the in vivo tests on blue mold incidence and severity was determined using generalized linear mixed models with the GLIMMIX procedure of SAS (version 9.4; SAS Institute). Differences in the mean incidence and severity for each treatment were determined using the lsmeans statement of GLIMMIX at the 5\% level of significance (SAS Institute) with a Tukey honest significant difference adjustment.

\section{Results}

Identification of Penicillium spp. isolates. A total of 97 monoconidial Penicillium spp. isolates, from different years, hosts, and sources, were identified to species by consensus $(2 \times)$ amplicon sequences of a partial $\beta$-tubulin gene using Basic Local Alignment Search Tool (BLAST) analysis. Percent identity (100 to 96\%), e value (0 to 6.00E-172), and top hit from GenBank accessions are reported in Table 1. Mean $\mathrm{EC}_{50}$ and percentile rank are also included for each isolate.

Penicillium spp. collection baseline sensitivity to difenoconazole. The 97 single-spore Penicillium spp. isolates collected from various locations, hosts, and environments had $\mathrm{EC}_{50}$ values of difenoconazole ranging from 0.038 to $0.827 \mathrm{mg} / \mathrm{liter}$ with a mean of 0.16 , median of 0.07 , and mode of $0.05 \mathrm{mg} / \mathrm{liter}$ (Table 2). Values representing the mean, median, and mode for Penicillium spp. isolates from pome fruit $(n=72)$, from storage $(n=53)$, and $P$. expansum isolates $(n=80)$ were nearly identical (Table 2$)$. Seventy-one percent of the isolates had $\mathrm{EC}_{50}$ values between 0.0381 and $0.1375 \mathrm{mg} /$ liter (Fig. 1). Difenoconazole at $5 \mathrm{mg} /$ liter inhibited the growth of all isolates except three, and $10 \mathrm{mg} /$ liter inhibited growth of all 97 isolates.

Postharvest fungicide phenotypes of Penicillium spp. isolates. Discriminatory doses for the active ingredients of three postharvest fungicides (FLU, TBZ, and PYR) were used to determine if

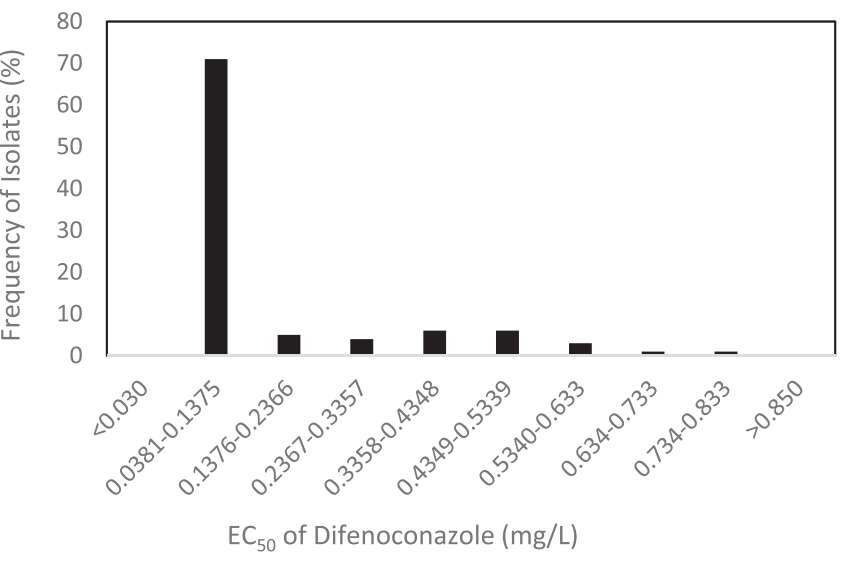

Fig. 1. Frequency distribution of isolates in fungicide concentration that inhibit mycelial growth by $50 \%\left(E_{50}\right)$ for technical-grade difenoconazole for 97 Penicillium spp. isolates. 
members of the baseline population, with respect to difenoconazole, had resistance to the active ingredients in other postharvest fungicides used to control apple blue mold. Analysis of seven P. expansum isolates and one $P$. solitum from all four quartiles in the baseline population revealed that three isolates in quartile 1 and one in quartile 4 were completely sensitive to all three active ingredients and did not grow on FLU-, PYR-, or TBZ-amended agar. Conversely, one isolate in quartile 2 grew on PYR, and one from quartile 3 grew on TBZ. Two isolates from quartile 4 grew on both TBZ and PYR and were considered dual resistant (Table 3). Growth rates ranged from 2.10 to $4.10 \mathrm{~mm} /$ day for isolates F-Fr-MD-8 (P. expansum), 16104 ( $P$. solitum), and $\mathrm{G} 10$ ( $P$. expansum). These three isolates were resistant to either TBZ and or PYR, whereas the other five $P$. expansum isolates (IIRS8a, P24, IIRS11, IIRR5, and 28886) were sensitive. Three isolates (IIRR5, 16104, and G10) grew on TBZ-amended medium at rates ranging from 1.1 to $7.1 \mathrm{~mm} /$ day and were resistant, whereas the other five isolates were sensitive. None of the eight isolates grew on FLU-amended PDA.

Efficacy of Academy fungicide to control apple blue mold. Academy, applied at the labeled rate of $16 \mathrm{fl} \mathrm{oz} / 100$ gal, reduced blue mold decay on apple fruit inoculated with four different $P$. expansum isolates having different levels of difenoconazole sensitivity (quartiles 1 to 4) from the baseline population. For fruit stored at $1{ }^{\circ} \mathrm{C}$ for 8 weeks, untreated controls had mean lesions ranging from 7.87 to $34.7 \mathrm{~mm}$ with incidence from 45 to $100 \%$ depending on the isolate. No decay occurred on apples subjected to curative treatments. Severity of lesions for the protectant treatment ranged from 5.78 to $14.4 \mathrm{~mm}$ and incidence of decay from 12.5 to $57.5 \%$
(Table 4). For fruit held at $22^{\circ} \mathrm{C}$ for 1 week after cold storage for 8 weeks, severity of decay for untreated controls ranged from 36.5 to $60.8 \mathrm{~mm}$ and incidence of decay from 65 to $100 \%$. For curative treatments, blue mold severity ranged from 0 to $1.24 \mathrm{~mm}$ and incidence from 0 to $7.5 \%$, and for protectant treatments severity ranged from 20.2 to $37.1 \mathrm{~mm}$ and incidence from 52.5 to $97.5 \%$ (Table 5).

\section{Discussion}

This is the first study to assess baseline sensitivity to difenoconazole in Penicillium spp. In 2015, Syngenta released a new postharvest fungicide formulation, Academy, containing FLU and difenoconazole to control blue mold on pome fruit. Previous work by Li and Xiao (2008) determined baseline sensitivity and a discriminatory dose for FLU, the active ingredient in the postharvest fungicide Scholar. However, baseline information and a corresponding discriminatory dose for difenoconazole are important for monitoring resistance to the components of Academy and hence necessitated the current investigation. We demonstrated that all the Penicillium spp. isolates tested were sensitive to difenoconazole, and only three that grew poorly on $5 \mu \mathrm{g} / \mathrm{ml}$ of difenoconazole were considered "reduced sensitive." The range for our Penicillium spp. baseline population was broader $(0.038$ to $0.827 \mu \mathrm{g} / \mathrm{ml})$ than what has been reported for Didymella bryoniae (causing gummy stem blight of cucurbits) isolates from Georgia ( 0.018 to $0.048 \mu \mathrm{g} / \mathrm{ml}$ ) (Thomas et al. 2012). It is tempting to hypothesize that the observed range may have resulted from using different Penicillium spp. in our studies, whereas Thomas et al. (2012) examined a single species of D. bryoniae. However, the $\mathrm{EC}_{50}$ range, mean, median, and mode for difenoconazole

Table 3. Mycelial growth rate in vitro of select Penicillium spp. isolates, based on $\mathrm{EC}_{50}$ values for difenoconazole (DIF), on potato dextrose agar ${ }^{\mathrm{Z}}$

\begin{tabular}{|c|c|c|c|c|c|c|c|}
\hline \multirow[b]{2}{*}{ Isolate } & \multirow[b]{2}{*}{ Penicillium spp. } & \multirow[b]{2}{*}{ Quartile rank } & \multirow[b]{2}{*}{$\mathrm{EC}_{50}$ DIF } & \multirow[b]{2}{*}{ Fungicide phenotype } & \multicolumn{3}{|c|}{ Mean growth rate (mm/day) } \\
\hline & & & & & $0.5 \mu \mathrm{g} / \mathrm{ml}$ FLU & $10.0 \mu \mathrm{g} / \mathrm{ml} \mathrm{TBZ}$ & $1.0 \mu \mathrm{g} / \mathrm{ml}$ PYR \\
\hline IIRS8a & P. expansum & 1 & 0.03 & $\mathrm{FLU}_{\mathrm{S}} \mathrm{TBZ}_{\mathrm{S}} \mathrm{PYR}_{\mathrm{S}}$ & 0 & 0 & 0 \\
\hline $\mathrm{P} 24$ & P. expansum & 1 & 0.04 & $\mathrm{FLU}_{\mathrm{S}} \mathrm{TBZ}_{\mathrm{S}} \mathrm{PYR}_{\mathrm{S}}$ & 0 & 0 & 0 \\
\hline IIRS11 & P. expansum & 1 & 0.05 & $\mathrm{FLU}_{\mathrm{S}} \mathrm{TBZ}_{\mathrm{S}} \mathrm{PYR}_{\mathrm{S}}$ & 0 & 0 & 0 \\
\hline F-Fr-MD-8 & P. expansum & 2 & 0.07 & $\mathrm{FLU}_{\mathrm{S}} \mathrm{TBZ}_{\mathrm{S}} \mathrm{PYR}_{\mathrm{R}}$ & 0 & 0 & 4.10 \\
\hline IIRR5 & P. expansum & 3 & 0.17 & $\mathrm{FLU}_{\mathrm{S}} \mathrm{TBZ}_{\mathrm{R}} \mathrm{PYR}_{\mathrm{R}}$ & 0 & 6.95 & 0 \\
\hline 16104 & P. solitum & 4 & 0.42 & $\mathrm{FLU}_{\mathrm{S}} \mathrm{TBZ}_{\mathrm{R}} \mathrm{PYR}_{\mathrm{R}}$ & 0 & 7.15 & 3.50 \\
\hline G10 & P. expansum & 4 & 0.53 & $\mathrm{FLU}_{\mathrm{S}} \mathrm{TBZ}_{\mathrm{R}} \mathrm{PYR}_{\mathrm{R}}$ & 0 & 1.16 & 2.10 \\
\hline 28886 & P. expansum & 4 & 0.83 & $\mathrm{FLU}_{\mathrm{S}} \mathrm{TBZ}_{\mathrm{S}} \mathrm{PYR}_{\mathrm{S}}$ & 0 & 0 & 0 \\
\hline
\end{tabular}

${ }^{\mathrm{z}}$ Potato dextrose agar amended with discriminatory doses of $0.5 \mu \mathrm{g} / \mathrm{ml}$ of fludioxonil (FLU) or $10 \mu \mathrm{g} / \mathrm{ml}$ of thiabendazole (TBZ), and Richards defined medium amended with $1.0 \mu \mathrm{g} / \mathrm{ml}$ of pyrimethanil (PYR). $\mathrm{R}=$ resistant; $\mathrm{S}=$ sensitive; and $\mathrm{EC}_{50}=$ the estimated concentration of a fungicide that results in $50 \%$ inhibition of mycelial growth.

Table 4. Analysis of blue mold decay control in apple fruit under commercial storage conditions ${ }^{\mathrm{y}}$

\begin{tabular}{|c|c|c|c|c|c|c|c|c|c|}
\hline \multirow[b]{2}{*}{ Isolate } & \multirow[b]{2}{*}{$\mathrm{EC}_{50} \mathrm{DIF}^{\mathrm{z}}$} & \multirow[b]{2}{*}{ Rank } & \multirow[b]{2}{*}{ Fungicide phenotype } & \multicolumn{3}{|c|}{ Severity (mm) (blue mold decay) } & \multicolumn{3}{|c|}{ Incidence (\%) (mean lesion size) } \\
\hline & & & & None & Protectant & Curative & None & Protectant & Curative \\
\hline IIRS8a & 0.03 & 1 & $\mathrm{FLU}_{\mathrm{S}} \mathrm{TBZ}_{\mathrm{S}} \mathrm{PYR}_{\mathrm{S}}$ & $33.1 \mathrm{a}$ & $14.4 \mathrm{~b}$ & $0 \mathrm{c}$ & $85 \mathrm{a}$ & $57.5 \mathrm{a}$ & $0 \mathrm{~b}$ \\
\hline F-Fr-MD-8 & 0.07 & 2 & $\mathrm{FLU}_{S} \mathrm{TBZ}_{\mathrm{S}} \mathrm{PYR}_{\mathrm{R}}$ & $29.0 \mathrm{a}$ & $8.71 \mathrm{~b}$ & $0 \mathrm{c}$ & $85 \mathrm{a}$ & $40 \mathrm{ab}$ & $0 \mathrm{~b}$ \\
\hline IIRR5 & 0.17 & 3 & $\mathrm{FLU}_{S} \mathrm{TBZ}_{\mathrm{R}} \mathrm{PYR}_{\mathrm{R}}$ & $34.7 \mathrm{a}$ & $5.78 \mathrm{~b}$ & $0 \mathrm{c}$ & $100 \mathrm{a}$ & $40 \mathrm{~b}$ & $0 \mathrm{~b}$ \\
\hline 28886 & 0.83 & 4 & $\mathrm{FLU}_{\mathrm{S}} \mathrm{TBZ}_{\mathrm{S}} \mathrm{PYR}_{\mathrm{S}}$ & $7.87 \mathrm{a}$ & $9.21 \mathrm{a}$ & $0 \mathrm{~b}$ & $45 \mathrm{a}$ & $12.5 \mathrm{a}$ & $0 \mathrm{a}$ \\
\hline
\end{tabular}

${ }^{\mathrm{y}}$ Apples were inoculated with one of four representative Penicillium expansum isolates from the baseline collection using the labeled rate of Academy fungicide and stored at $1^{\circ} \mathrm{C}$ in air for 8 weeks.

${ }^{\mathrm{z}} \mathrm{EC}_{50}=$ the estimated concentration of a fungicide that results in 50\% inhibition of mycelial growth; and DIF $=$ difenoconazole.

Table 5. Analysis of blue mold decay control in apple fruit under commercial storage and display conditions ${ }^{\mathrm{y}}$

\begin{tabular}{|c|c|c|c|c|c|c|c|c|c|}
\hline \multirow[b]{2}{*}{ Isolate } & \multirow[b]{2}{*}{$\mathrm{EC}_{50} \mathrm{DIF}^{\mathrm{z}}$} & \multirow[b]{2}{*}{ Rank } & \multirow[b]{2}{*}{ Fungicide phenotype } & \multicolumn{3}{|c|}{ Severity (mm) (blue mold decay) } & \multicolumn{3}{|c|}{ Incidence (\%) (mean lesion size) } \\
\hline & & & & None & Protectant & Curative & None & Protectant & Curative \\
\hline IIRS8a & 0.03 & 1 & $\mathrm{FLU}_{\mathrm{S}} \mathrm{TBZ}_{\mathrm{S}} \mathrm{PYR}_{\mathrm{S}}$ & $60.8 \mathrm{a}$ & $37.1 \mathrm{~b}$ & $0 \mathrm{c}$ & 90 a & $82.5 \mathrm{a}$ & $0 \mathrm{~b}$ \\
\hline F-Fr-MD-8 & 0.07 & 2 & $\mathrm{FLU}_{\mathrm{S}} \mathrm{TBZ}_{\mathrm{S}} \mathrm{PYR}_{\mathrm{R}}$ & $59.7 \mathrm{a}$ & $24.8 \mathrm{~b}$ & $0 \mathrm{c}$ & $95 \mathrm{a}$ & $75 \mathrm{a}$ & $5 \mathrm{~b}$ \\
\hline IIRR5 & 0.17 & 3 & $\mathrm{FLU}_{\mathrm{S}} \mathrm{TBZ}_{\mathrm{R}} \mathrm{PYR}_{\mathrm{R}}$ & $66.2 \mathrm{a}$ & $33.0 \mathrm{~b}$ & $1.24 \mathrm{c}$ & $100 \mathrm{a}$ & $97.5 \mathrm{a}$ & $7.5 \mathrm{~b}$ \\
\hline 28886 & 0.83 & 4 & $\mathrm{FLU}_{\mathrm{S}} \mathrm{TBZ}_{\mathrm{S}} \mathrm{PYR}_{\mathrm{S}}$ & $36.5 \mathrm{a}$ & $20.2 \mathrm{~b}$ & $0.44 \mathrm{c}$ & $65 \mathrm{a}$ & $52.5 \mathrm{a}$ & $0 \mathrm{~b}$ \\
\hline
\end{tabular}

${ }^{y}$ Apples were inoculated with one of four representative Penicillium expansum isolates from the baseline collection using the labeled rate of Academy fungicide and stored at $1{ }^{\circ} \mathrm{C}$ in air for 8 weeks followed by 1 week at $22^{\circ} \mathrm{C}$.

${ }^{\mathrm{z}} \mathrm{EC}_{50}=$ the estimated concentration of a fungicide that results in 50\% inhibition of mycelial growth; and DIF $=$ difenoconazole. 
for the entire population $(n=97)$ and $P$. expansum only $(n=80)$ were nearly identical. Hence, the contribution of different Penicillium species appears to have had a negligible impact on the observed broad sensitivity range. Interestingly, it appears that isolate source may be a larger contributing factor that influences difenoconazole sensitivity, because a narrower range $(0.040$ to $0.590 \mu \mathrm{g} / \mathrm{ml})$ was observed with similar values in mean, median, and mode for isolates obtained from pome fruit and a storage environment.

To assess the prevalence of resistance to other postharvest fungicides among the collection of Penicillium spp., eight representative isolates were selected based on their different levels of sensitivity to difenoconazole. $\mathrm{EC}_{50}$ values ranged from 0.03 to $0.83 \mu \mathrm{g} / \mathrm{ml}$ for difenoconazole, and half of them were sensitive to FLU, TBZ, and PYR, whereas two had dual resistance to TBZ and PYR, one was resistant to PYR, and one to TBZ. All isolates analyzed in this study were collected before difenoconazole was labeled for postharvest use. Therefore, these Penicillium spp. isolates could have not been exposed to difenoconazole or other demethylation inhibitors (DMIs) as a postharvest treatment. However, exposure to TBZ, PYR, and/or FLU is expected, because some of the isolates were collected from storage facilities with histories of postharvest fungicide applications via Mertect, Penbotec, and Scholar to control blue mold. Given the postharvest application history, all eight isolates were sensitive to FLU, which from a practical standpoint is reasonable, because these two compounds would not have been included together in the same formulation if there was potential for cross-resistance. Previous investigations in Penicillium spp. and Botrytis cinerea have shown that no significant cross-sensitivity exists between TBZ, FLU, and PYR (Forster and Staub 1996; Kanetis et al. 2004; Li and Xiao 2008). Hence, investigation of cross-resistance with existing materials and those not currently labeled for pome fruit was not warranted. However, the impact of similar mode of action fungicides (DMIs) used in the field (such as Inspire Super for scab control) may influence postharvest efficacy in the packinghouse using Academy, which is the subject of future investigation.

The effective control of blue mold incited by different $P$. expansum strains with differing sensitivities to difenoconazole by Academy at the labeled rate included one isolate with resistance to PYR and one isolate with dual resistane to TBZ and PYR. This gives growers a viable control option for blue mold decay in the presence of postharvest fungicide-resistant isolates, which are prevalent in the Mid-Atlantic and West Coast apple-producing regions (Amiri et al. 2017; Gaskins et al. 2015; Yan et al. 2014). In theory, a fungal spore could land in a wound on apple fruit in the field and be carried to the packinghouse, where it gets treated with fungicide (i.e., representing a curative treatment). The converse situation may also occur in which the fruit enter the packinghouse unblemished, and then fruit get bruised or punctured during handling and encounter fungal spores after fungicide (drenching) treatment (i.e., mimicking a protectant treatment). Therefore, we saw a need to investigate both curative and protectant treatments of Academy to control blue mold. Curative treatments resulted in no detectable levels of decay, whereas protectant applications were more effective than the untreated controls but still developed blue mold. This may have resulted from a longer direct contact of the fungicide in the wound with the fungal spores in the curative treatments than in the protectant ones. Additionally, the rate and concentration at which the active ingredients (FLU and difenoconazole) penetrate and move through the apple cortex may also be a factor governing the effectiveness of the material as a protectant for wounds that are made after fungicides are applied. Our observations are consistent with work done by Xiao and Boal (2009), which showed that FLU moved only $5 \mathrm{~mm}$ into the apple flesh following 5 months of storage. Hence, the penetrating capacity of FLU is apparent, but limited, whereas absorption, movement, and stability of difenoconazole in apple tissue have not been published in the literature to date. Even though the curative treatments were more efficacious, they began to lose efficacy after additional incubation for 1 week at $22^{\circ} \mathrm{C}$ (to mimic consumer/grocery chain shelves) after cold storage, which may have occurred because of fungistatic action and may have dissipated over time, thereby allowing germination of spores that were originally suppressed. It is also likely that more aggressive fungal growth occurred in the wound at the higher storage temperature, which may also have affected the stability of either FLU or difenoconazole, resulting in increased decay. However, more research on chemical stability, metabolism in the fruit, and how temperature and other storage practices influence these variables is needed and should be the subject of future investigations.

In summary, the baseline sensitivity of 97 Penicillium spp. isolated from various locations, environments, and hosts to difenoconazole was established. The wide range (approximately 27.6-fold) of sensitivity to difenoconazole suggests that this fungal population was most likely unexposed to DMIs previously. There is a remote chance that two isolates with higher $\mathrm{EC}_{50}$ values (isolates 28886 from grape [0.827] and 35178 from green coffee bean [0.710]) may have been previously exposed to other DMIs in the field that are used for fungal diseases in the field. However, these two isolates may also represent natural variation in the population with respect to difenoconazole sensitivity. The discriminatory concentration of $5 \mu \mathrm{g} / \mathrm{ml}$ was established for early detection and screening for development of resistance to aid fungicide resistance management decisions. Control of TBZ and TBZ/PYR dual resistant $P$. expansum isolates, along with isolates completely sensitive FLU and difenoconazole, was achieved using the labeled rate of Academy postharvest fungicide. Our study demonstrated that Academy is a viable option for rotation with other decay-control products to achieve more sustainable control of apple blue mold, which may also result in reduced patulin contamination of processed apple fruit products and ultimately impact efforts to reduce food waste.

\section{Acknowledgments}

We thank the commercial storage facilities, packers, producers, and the MidAtlantic pome fruit industry who allowed us access to their facilities to obtain this diverse set of Penicillium spp. isolates.

\section{Literature Cited}

Amiri, A., Mulvaney, K. A., and Pandit, K. L. 2017. First report of Penicillium expansum isolates with low levels of resistance to fludioxonil from commercial apple packinghouses in Washington State. Plant Dis. 101:835.

Bertrand, P. F., and Saulie-Carter, J. L. 1978. The occurrence of benomyl tolerant strains of Penicillium expansum and Botrytis cinerea in the mid-Columbia region of Oregon and Washington. Plant Dis. Rep. 62:302-305.

Boysen, M., Shouboe, P., Frisvad, J., and Rossen, L. 1996. Reclassification of the Penicillium roquefortii group into three species on the basis of molecular genetic and biochemical profiles. Microbiology 142:541-549.

Errampalli, D. 2004. Effect of fludioxonil on germination and growth of Penicillium expansum and decay in apple cvs. Empire and Gala. Crop Prot. 23:811-817.

Errampalli, D., and Brubacher, N. R. 2006. Biological and integrated control of postharvest blue mold (Penicillium expansum) of apples by Pseudomonas syringae and cyprodinil. Biol. Control 36:49-56.

Forster, B., and Staub, T. 1996. Basis for use strategies of anilinopyrimidine and phenylpyrrole fungicides against Botrytis cinerea. Crop Prot. 15:529-537.

Frisvad, J., and Samson, R. A. 2004. Polyphasic taxonomy of Penicillium subgenus Penicillium: A guide to identification of food and air-borne terverticillate Penicillia and their mycotoxins. Stud. Mycol. 49:1-174.

Gaskins, V. L., Vico, I., Yu, J., and Jurick, W. M., II. 2015. First report of Penicillium expansum isolates with reduced sensitivity to fludioxonil from a commercial packinghouse in Pennsylvania. Plant Dis. 99:1182.

Janisiewicz, W. J., and Jeffers, S. N. 1997. Efficacy of commercial formulation of two biofungicides for control of blue mold and gray mold of apples in cold storage. Crop Prot. 16:629-633.

Jurick, W. M., II, Macarisin, O., Gaskins, V. L., Park, E., Yu, J., Janisiewicz, W. J., and Peter, K. A. 2017. Characterization of postharvest fungicide-resistant Botrytis cinerea isolates from commercially stored apple fruit. Phytopathology 107:362-368.

Kanetis, L., Soto-Estrada, A., and Adaskaveg, J. E. 2004. Baseline sensitivities of Penicillium digitatum populations to azoxystobin, fludioxonil and pyrimethanil. Phytopathology 94:S49 (Abstr.).

Li, H. X., and Xiao, C. L. 2008. Baseline sensitivities to fludioxonil and pyrimethanil in Penicillium expansum populations from apple in Washington State. Postharvest Biol. Technol. 47:239-245.

Peter, K. A., Vico, I., Gaskins, V. L., Janisiewicz, W. J., Saftner, R. A., and Jurick, W. M., II. 2012. First report of Penicillium carneum causing blue mold on stored apples in Pennsylvania. Plant Dis. 96:1823.

Pitt, J. I. 2002. A Laboratory Guide to Common Penicillium Species. Food Science Australia, North Ryde, NSW. 
Rosenberger, D. A. 1990. Blue mold. Pages 54-55 in: Compendium of Apple and Pear Diseases. A. L. Jones and H. S. Aldwinkle, eds. APS Press, Saint Paul, MN.

Rosenberger, D. A. 2012. Sanitize apple storage rooms to minimize postharvest decays. Scaffolds Fruit J. 21:4-5.

Rosenberger, D. A., Engle, C. A., Meyer, F. W., and Watkins, C. B. 2006. Penicillium expansum invades apples through stems during controlled atmosphere storage. Plant Health Prog. 7.

Russell, P. E. 2004. Sensitivity Baselines in Fungicide Resistance Research and Management. FRAC Monograph 3. Crop Life International, Brussels, Belgium.

Sanderson, P. G., and Spotts, R. A. 1995. Postharvest decay of winter pear and apple fruit caused by species of Penicillium. Phytopathology 85:103-110.

Sholberg, P. L., and Haag, P. D. 1996. Incidence of postharvest pathogens of stored apples in British Columbia. Can. J. Plant Pathol. 18:81-85.

Sholberg, P. L., Harlton, C., Haag, P., Lévesque, C. A., Gorman, D. O., and Seifert, K. 2005. Benzimidazole and diphenylamine sensitivity and identity of
Penicillium spp. that cause postharvest blue mold of apples using $\beta$-tubulin gene sequences. Postharvest Biol. Technol. 36:41-49.

Spotts, R. A., Cervantes, L. A., and Mielke, E. A. 1999. Variability in postharvest decay among apple cultivars. Plant Dis. 83:1051-1054.

Thomas, A., Langston, D. B., Jr., and Stevenson, K. L. 2012. Baseline sensitivity and cross resistance to succinate dehydrogenase inhibiting and demethylation inhibiting fungicides in Didymella broniae. Plant Dis. 96:979-984.

Xiao, C. L., and Boal, R. J. 2009. Residual activity of fludioxonil and pyrimethanil against Penicillium expansum on apple fruit. Plant Dis. 93:1003-1008.

Xiao, C. L., and Boal, R. J. 2013. Biological control of Phacidiopycnis rot in 'd'Anjou' pears. Acta Hortic. 1001:255-258

Xiao, C. L., and Kim, Y. K. 2008. Postharvest fruit rots in apples caused by Botrytis cinerea, Phacidiopycnis washingtonensis, and Sphaeropsis pyriputrescens. Online publication. Plant Health Prog. 9.

Yan, H., Gaskins, V. L., Vico, I., Luo, Y., and Jurick, W. M., II. 2014. First report of Penicillium expansum isolates resistant to pyrimethanil from stored apple fruit in Pennsylvania. Plant Dis. 98:7. 